Laporan Kasus

\title{
Diagnosis dan Penatalaksanaan Abses Retrofaring pada Anak
}

\author{
Novialdi, Dolly Irfandy
}

\begin{abstract}
Abstrak
Pendahuluan: Abses retrofaring adalah terkumpulnya nanah di ruang retrofaring yang merupakan salah satu daerah potensial di leher dalam. Abses retrofaring merupakan kasus yang jarang tetapi dapat menyebabkan kematian terutama pada umur di bawah 5 tahun. Sejak ditemukannya antibiotika, angka kesakitan dan kematian akibat abses menurun drastis. Metode: Dilaporkan satu kasus abses retrofaring dengan riwayat ketulangan pada anak gizi kurang umur 9 tahun. Diagnosis ditegakkan berdasarkan anamnesis, pemeriksaan fisik dan pemeriksaan radiologi. Pada pemeriksaan foto polos jaringan lunak leher, terlihat gambaran pelebaran ruang retrofaring dan air fluid level. Diskusi: Penatalaksanaan meliputi pemberian antibiotika, drainase dan eksplorasi abses serta perbaikan keadaan umum.
\end{abstract}

Kata kunci: abses retrofaring, benda asing, drainase

\section{Abstract}

Introduction: Retropharyngeal abscess is defined as accumulation pus in retropharyngeal space which is a potential area in deep neck space. Retropharyngeal abscess is a rare case but it can cause death especially in children under five years old. Since antibiotics were found, morbidity and mortality of this case was drastically decreased. Methods: A retropharyngeal abscess of child 9 years old with history of swallowed foreign body (fishbone) and lack of nutrition has been reported. Diagnosis was based on anamnesis, physical examination and radiographic finding. In soft tissue cervical radiograph we found, widening of retropharyngeal space with air fluid level. Discussion: Management for abscess is intravenous antibiotics, drainage and exploration abscess and improve general condition has been performed

Keywords:Retropharyngeal abscess, foreign body, drainage

Affiliasi penulis : Bagian THT-KL Fak. Kedokteran Univ. Andalas Korespondensi :d_irfandy@yahoo.com

\section{endahuluan}

Ruang retrofaring merupakan salah satu daerah potensial di leher dalam. Abses retrofaring adalah terkumpulnya nanah di ruang retrofaring. Pada bayi dan anak usia kurang dari lima tahun lebih sering terjadi akibat penjalaran infeksi. Sedangkan pada anak di atas umur 6 tahun, lebih sering disebabkan trauma tindakan medis seperti adenoidektomi, intubasi endotrakea dan endoskopi maupun oleh trauma benda asing. $^{1-8}$

Ruang retrofaring merupakan ruang potensial yang terletak diantara lapisan tengah fasia leher dalam yang mengelilingi faring dan esofagus di sebelah anterior dan lapisan dalam fasia leher dalam di sebelah posterior. Ruang ini memanjang dari dasar tengkorak yang merupakan batas superior sampai ke mediastinum setinggi vertebra torakal pertama atau kedua yang merupakan batas inferior., ${ }^{1,3,9}$

Ruang ini berisi kelenjar limfe setingg vertebra servikal 2-3, yang berjumlah 2-5 buah (nodes of rouviere) pada sisi kanan dan kiri. Kelenjar ini menampung aliran limfe dari hidung, sinus paranasal, nasofaring, faring, tuba Eustachius dan telinga tengah. Kelenjar ini berkembang selama satu tahun pertama dan ditemukan ukuran terbesar pada usia 5 tahun. ${ }^{1,3,8,9}$ Abses retrofaring biasanya berasal dari supurasi kelenjar-kelenjar tersebut sehingga lokasi abses lebih cenderung agak ke lateral. ${ }^{1}$

Gejala klinis abses retrofaring berbeda antara dewasa dan anak. Pada anak biasanya didahului oleh infeksi saluran nafas. Permulaan gejala biasanya tidak spesifik seperti anak menangis terus-menerus (rewel), tidak mau makan atau minum, demam, kekakuan dan nyeri tekan pada leher. ${ }^{1,2,16}$ Infeksi dapat meluas ke mediastinum yang ditandai dengan gejala demam, nyeri dada, sesak nafas yang bertambah berat. ${ }^{1-6,10,11}$

Wholey menyimpulkan bahwa bila ukuran retrofaring pada anak dan dewasa lebih dari $7 \mathrm{~mm}$, ukuran retrotrakeal pada anak lebih $14 \mathrm{~mm}$ dan pada dewasa lebih $22 \mathrm{~mm}$, maka dicurigai adanya proses patologik pada ruang retrofaring. Ruang retrofaring diukur dari jarak antara anteroinferior vertebra servikal dua dengan dinding posterior faring. Ruang retrotrakeal diukur dari jarak antara anteroinferior vertebra servikal enam dengan dinding posterior trakea. ${ }^{2,3,9,12}$

Sensitivitas TK pada abses leher dalam termasuk abses retrofaring sekitar $90 \%$ dengan tingkat spesifisitas $60 \%$. $^{13,18}$

Tindakan eksplorasi abses dapat melalui transoral maupun eksternal. Pada abses yang masih terlokalisasi dan tidak ada tanda obstruksi jalan nafas, maka insisi transoral dapat dilakukan dalam posisi kepala lebih rendah (Rose) untuk menghindari terjadi aspirasi. Insisi transoral dan drainase dilakukan pada $83 \%$ kasus dan $78 \%$ kasus dalam penanganan abses retrofaring. ${ }^{17,18}$ Pada abses yang cukup besar dan meluas ke arah hipofaring insisi transoral tidak cukup menjamin drainase yang baik, sehingga disarankan melakukan insisi eksternal. ${ }^{1-3,6}$ Jumlah hari rawatan pada kasus-kasus abses retrofaring pada salah satu kepustakaan adalah 4-51 hari dengan rerata 14,1 hari. $^{16}$ 


\section{Laporan Kasus}

Seorang pasien anak laki-laki umur 9 tahun datang ke IGD RS.M.Djamil tanggal 3 November 2008 rujukan dari RSUD Painan dengan keluhan tidak dapat menelan sejak 7 hari yang lalu dan demam. Sepuluh hari sebelumnya pasien ketulangan, kemudian keluarga membawa pasien berobat ke dokter umum dan diberi obat tablet.

Karena pasien susah menelan, obat yang diberikan oleh dokter tidak diminum. Tiga hari kemudian, keluarga membawa pasien ke rumah sakit umum daerah dan dirawat selama dua hari. Dalam perawatan pasien dirujuk ke RS. M. Djamil karena dari mulut pasien mengeluarkan nanah yang berbau busuk dan bercampur darah.

Pada pemeriksaan fisik terlihat keadaan umum tampak sakit berat, kesadaran komposmentis, suhu $37,8^{\circ} \mathrm{C}$, nadi $94 \mathrm{x} / \mathrm{menit}$ frekuensi nafas $60 \mathrm{x} /$ menit, berat badan $20 \mathrm{~kg}$

Dari pemeriksaan THT didapatkan telinga dan hidung dalam batas normal. Tenggorok terlihat arkus faring simetris, uvula di tengah, tonsil T2-T2, tampak dinding faring posterior menonjol dan fluktuatif, hiperemis dan tampak pus pada dinding faring posterior (orofaring). Ditemukan stridor inspirasi dan retraksi suprasternal. Leher sakit jika digerakkan. Benjolan di leher tidak ada. Saat batuk mengeluarkan sekret kental bernanah dan bercampur darah.

Dilakukan pemeriksaan foto polos servikal dan thorakal. Pada foto polos servikal tampak penebalan pada daerah retrofaring (dari servikal 2 sampai servikal-5).

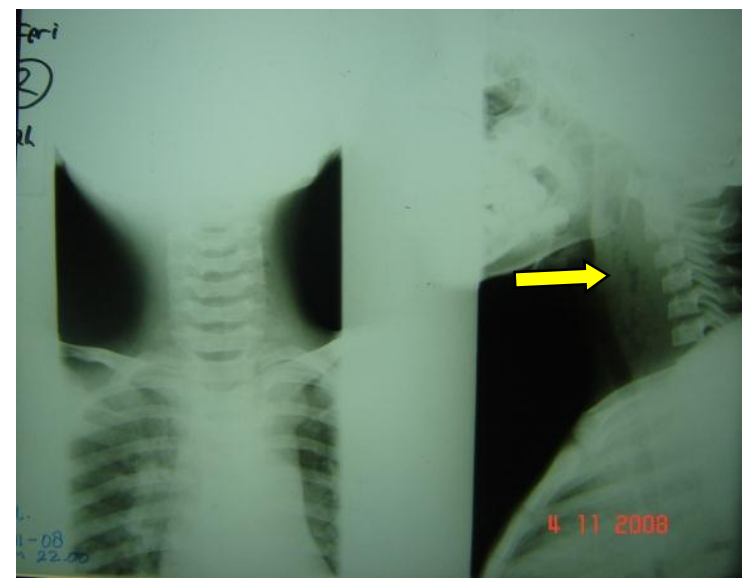

Gambar 3. Foto polos servikal AP/ Lateral

Hasil pemeriksaan laboratorium: $\mathrm{Hb} \quad 11,7$ $\mathrm{gr} / \mathrm{dl}$, hematokrit $35 \mathrm{vol} \%$, leukosit $20.100 / \mathrm{mm}^{3}$, trombosit $538.000 / \mathrm{mm}^{3}$. Fungsi hemostasis, ginjal, dan hati dalam batas normal. Elektrolit $\mathrm{Na} 128 \mathrm{mEQ} / \mathrm{L}, \mathrm{K}$ $3,4, \mathrm{mEq} / \mathrm{L}, \mathrm{Cl} 94 \mathrm{mEq} / \mathrm{L}$. Analisa gas darah $\mathrm{pH} 7,237$ $\mathrm{mmHg}$, PCO2 37,6 mmHg, PO2 130,7 mmHg, HCO3 $17,2 \mathrm{mEq} / \mathrm{L}$, Sat O2 98,2\%.

Pasien didiagnosis dengan abses retrofaring dengan obstruksi saluran nafas atas grade I dan sepsis. Penatalaksanaan saat itu adalah dipasang IVFD, pasien ditidurkan dengan posisi trendelenberg, diberi antibiotika Seftriaxone iv (skin test) $2 \times 1 \mathrm{gr}$, Metronidazol drip 3x250 mg, dan direncanakan untuk dilakukan insisi dan eksplorasi dalam anestesi umum. Pasien dikonsulkan ke bagian Anastesi dan bagian IImu Kesehatan Anak.
Dalam persiapan tiba-tiba pasien batuk-batuk dan dari mulut mengeluarkan pus yang kental dan berbau busuk bercampur darah sebanyak $\pm 20 \mathrm{cc}$. Saat itu juga posisi pasien dimiringkan dan dibantu membersihkan pus yang keluar dari mulut dengan suction.

Pasien langsung dibawa ke OK IGD, disiapkan untuk dilakukan insisi dan eksplorasi. Pasien tidur terlentang dalam anestesi umum dan di intubasi. Dilakukan prosedur antiseptik dan aseptik pada lapangan operasi. Dengan menggunakan laringoskop dilakukan evaluasi daerah faring, didapatkan pus pada permukaan dinding faring posterior (daerah orofaring), dilakukan kultur dari pus yang diambil sebelum insisi intra oral dilakukan. Pus diambil dengan spuit steril kemudian dikirim ke laboratorium untuk dilakukan kultur dan tes sensitivitas.

Daerah yang diinsisi kemudian dibersihkan, terlihat daerah yang ruptur dari abses. Daerah ruptur diperluas secara vertikal sepanjang $1,5 \mathrm{~cm}$. Dilakukan eksplorasi daerah insisi dengan menggunakan klem, didapatkan pus, berbau sangat busuk dan bercampur darah sekitar $\pm 200 \mathrm{cc}$. Dicoba mencari benda asing, tetapi tidak ditemukan. Diputuskan untuk menghentikan eksplorasi dan dipasang NGT.

Pasien dirawat di bangsal THT-KL dengan posisi Trandelenberg dan miring ke salah satu sisi, seftriaxone $2 \times 1 \mathrm{gr}$ (iv), metronidazole $3 \times 250 \mathrm{mg}$ drip, dexamethasone $3 \times 2 \mathrm{mg}$ (iv), ranitidine $2 \times 25 \mathrm{mg}$ (iv). Pada hari pertama $(4 / 10 / 08)$ perawatan pasien muntah pus bercampur darah kira-kira $30 \mathrm{cc}$ dianjurkan tambahan pemberian transamin 3x250 mg. Demam dan sesak nafas tidak ada, nyeri menelan. Dilakukan pemeriksaan rontgen foto thoraks dengan hasil infiltrat di perihiler dan parakardial disertai penebalan hilus dan perpadatan, kesan TB paru.

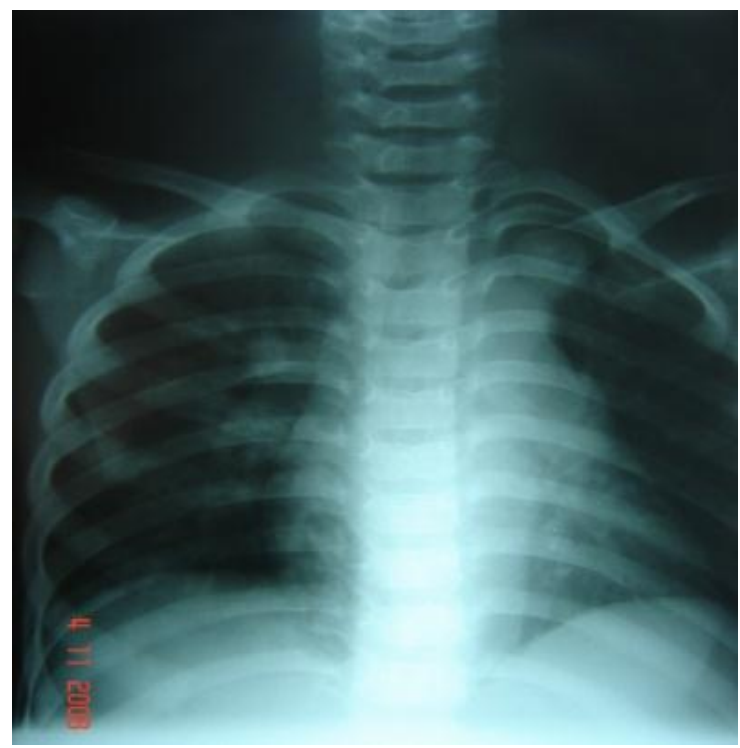

Gambar 4. Foto Thoraks AP 


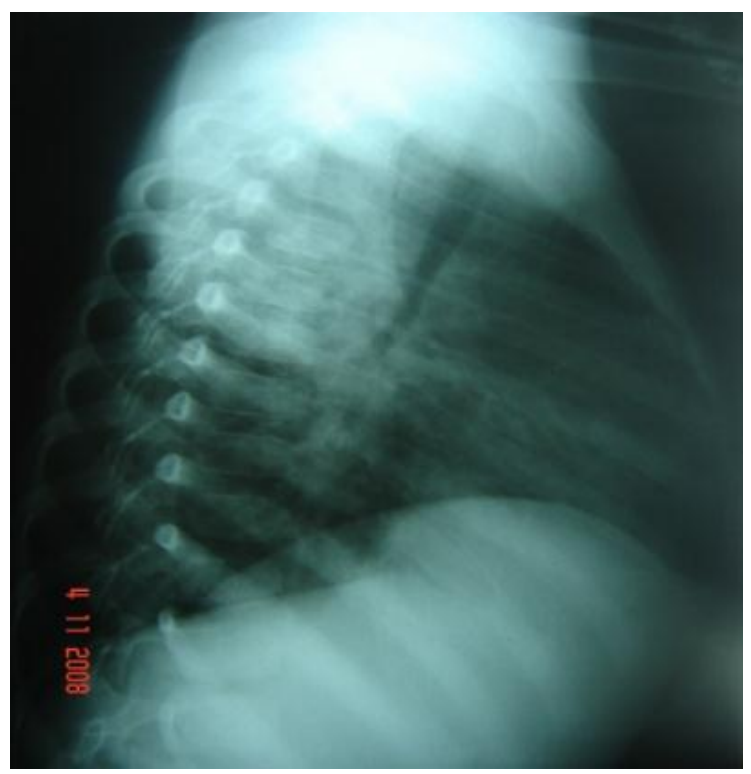

Gambar 5. Foto Thoraks Lateral

Pada tanggal 5 November 2008 (hari rawatan kedua), dari mulut pasien masih mengeluarkan pus bercampur darah, suhu $37,8^{\circ} \mathrm{C}$ dan frekuensi nafas $20 \mathrm{x} /$ menit. Pada pemeriksaan THT didapatkan telinga dan hidung dalam batas normal. Tenggorok terlihat arkus faring simetris, uvula ditengah, tonsil T2-T2, dinding faring posterior masih tampak menonjol dan terlihat pus bercampur darah. Pada pemeriksaan foto polos servikal AP dan Lateral masih tampak penebalan di daerah retrofaring (servikal 2- servikal 5). Pasien di konsulkan ke bagian IKA untuk evaluasi dan penatalaksanaan bersama. Hasil konsul IKA; TB paru? dengan gizi kurang, setuju rawat bersama dengan subbagian Respirologi anak dan subbagian Gizi.

Pemberian antibiotik pada pasien sudah tepat sesuai dosis, diet makanan cair $8 \times 250 \mathrm{cc}$ per sonde, pemberian Asam Traneksamat $3 \times 300 \mathrm{mg}$ dan vitamin $\mathrm{K} \quad 2,5 \mathrm{mg}$ (selama 3 hari). Dianjurkan tes mantoux, BTA lambung dan pemeriksaan kultur dan sensitivitas dengan kemungkinan penyebab kuman banal.

Dilakukan uji mantoux $(5 / 11 / 08)$ pada pasien dan didapatkan hasil negatif (dibaca 7/11/08 dan 8/11/08). Hasil kultur pus dan sensitivitas dilakukan pada rawatan pertama dan didapatkan hasil (6/11/08) Staphylococcus aureus yang sensitif terhadap kloramfenikol, eritromisin, gentamisin dan seftriaxone. Anjuran dari Subbagian Laring Faring pemberian Gentamisin 2x40 mg selama 5 hari.

Tanggal 10 November 2008 (hari rawatan 8) pasien masih mengeluhkan nyeri menelan, sesak nafas tidak ada, demam tidak ada, nyeri didaerah dada tidak ada, batuk tidak ada, dari mulut masih mengeluarkan ludah bercampur nanah. Pada pemeriksaan tenggorokan, arkus faring simetris, uvula ditengah, tosil T2-T2, terlihat sedikit kumpulan pus dan ludah di dinding faring posterior. Hasil laboratorium: $\mathrm{Hb} 10,3 \mathrm{~g} / \mathrm{dl}$, leukosit 8500/UI, trombosit 561.000/Ul. Fungsi hati, ginjal dan hemostasis dalam batas normal. Diberikan terapi diet MC $8 \times 250 \mathrm{cc}$ per sonde, seftriaxone 2x1gr, dexamethasone $2 x 2 \mathrm{mg}$ dan Ranitidine 2x $25 \mathrm{mg}$.

Tanggal 17 November 2008 (rawatan hari ke-14) nyeri menelan masih ada, keluar nanah bercampur air ludah dari mulut tidak ada, nafas sesak tidak ada, perut terasa sakit. Tenggorokan dalam batas normal. Dilakukan pemeriksaan foto polos servikal AP dan Lateral dengan hasil tidak tampak kelainan pada daerah retrofaring. Terapi antibiotik diteruskan, dexamethasone dan ranitidine dihentikan. Kemudian diberikan sirup antasida $3 \times 1$ sendok teh. Diet mulai diberikan makanan lunak karena NGT pasien dicabut.

Pada tanggal 22 November 2008 (rawatan hari ke 19) pasien dipulangkan dan mendapat terapi klindamisin tablet $3 \times 150 \mathrm{mg}$ dan vitamin. Pada tanggal 3 desember 2008 pasien kontrol dengan keluhan tidak ada dan ada kenaikan berat badan $3 \mathrm{~kg}$ (berat awal masuk Rumah sakit $20 \mathrm{~kg}$ ).

Pada tanggal 19 Desember 2008 hasil kultur sputum yaitu Klebsiella $s p$, Pseudomonas aeruginosa yang sensitif terhadap siprofloksasin, sefoperazone dan kloramfenikol dan tidak ditemukan kuman BTA.

Pada saat kontrol kedua (27 Desember 2008), keluhan pasien tidak ada, keadaan umum pasien semakin membaik dan ada penambahan berat badan (saat kontrol kedua berat badan pasien $24,5 \mathrm{~kg}$ ).

\section{Diskusi}

Telah dilaporkan satu kasus abses retrofaring yang diduga disebabkan ketulangan pada seorang anak umur 9 tahun. Kasus abses retrofaring pada anak kurang dari lima tahun umumnya disebabkan oleh infeksi saluran nafas atas. Pada anak lebih lima tahun dan dewasa penyebabnya adalah trauma dan benda asing. ${ }^{1,2,8}$

Dari anamnesis didapatkan keluhan demam, tidak dapat menelan dan riwayat ketulangan. Singh ${ }^{10}$ dkk mendapatkan 93\% kasus benda asing di faring, laring dan esofagus yang memiliki riwayat tertelan benda asing dan gejala yang jelas. Adanya riwayat ketulangan sepuluh hari yang lalu menyebabkan reaksi jaringan dan terjadi infeksi. Infeksi yang terjadi berlanjut dikarenakan tidak mendapat pengobatan yang adekuat sehingga terbentuk abses. ${ }^{3}$ Singh $\mathrm{dkk}^{10}$ pada penelitiannya mendapatkan keluhan dan gejala yang lambat ( \pm 1 minggu) sebanyak $5,4 \%$.

Seiring dengan bertambah besarnya abses, pasien mengeluhkan sulit dan nyeri menelan serta demam, nyeri jika leher digerakkan, tetapi tidak ditemukan massa di leher. Craig $\mathrm{dkk}^{8}$ melaporkan gejala yang sering dijumpai adalah demam (78\%), nyeri leher $(67 \%)$, benjolan di leher $(55 \%)$, nyeri menelan (38\%), batuk (20\%), terbatas gerak leher untuk ekstensi (45\%), terbatas gerak leher untuk flexi $(12,5 \%)$, stridor $(1 \%)$.

Pada pemeriksaan tenggorok didapatkan dinding faring posterior menonjol dan hiperemis. Pada anak-anak kadang sulit untuk melihat dinding faring posterior karena mulut yang kecil dan adanya hipersalivasi. ${ }^{1,2}$ Pada pasien ini selain hipersalivasi ditemukan juga kumpulan nanah bercampur darah dan berbau busuk di dinding faring posterior (daerah orofaring).

Pada pemeriksaan darah tepi ditemukan leukosit pasien $20.100 / \mathrm{mm}^{3}$, rerata hitung leukosit pada salah satu studi adalah $17.000 / \mathrm{mm}^{3}$ (3100$\left.45900 / \mathrm{mm}^{3}\right) .{ }^{11}$ bahkan dari salah satu kepustakaan disebutkan $91 \%$ terdapat leukositosis dengan rerata $22.400 / \mathrm{mm}^{3}$. $^{17}$ Sekitar $18 \%$ kasus ditemukan hitung leukosit yang normal dan kurang $8000 / \mathrm{mm}^{3}$. Jadi belum tentu leukosit normal menyingkirkan suatu abses retrofaring. ${ }^{11}$

Pemeriksaan foto polos jaringan lunak servikal dapat melihat adanya penebalan daerah retrofaring dan terlihat gambaran radiolusen. Menurut 
Wholey seperti yang dikutip oleh Goldenberg ${ }^{2}$ jika ukuran retrofaring lebih dari $7 \mathrm{~mm}$ pada anak dan dewasa, ukuran retrotrakeal lebih dari $14 \mathrm{~mm}$ pada anak dan $22 \mathrm{~mm}$ pada dewasa dicurigai adanya proses patologik. Pada pasien ini terlihat penonjolan daerah retrofaring pada proyeksi cervikal 2 sampai cervikal 5, udara yang terperangkap dan air fluid level. Pasien didiagnosis dengan abses retrofaring dengan riwayat benda asing organik (ketulangan).

Pasien direncanakan untuk dilakukan insis dan eksplorasi. Sementara menunggu persiapan, tibatiba pasien batuk sehingga abses pecah. Pecahnya abses secara tiba-tiba merupakan kondisi yang berbahaya, karena dapat terjadi aspirasi pus dan menyebabkan pneumonia yang berat dan sumbatan

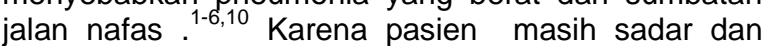
dalam posisi tredelenberg maka aspirasi dapat dicegah. Pasien dapat mengeluarkan pus dari dalam mulutnya dan dibantu penyedotan dengan suction.

Tindakan eksplorasi dan drainase abses dapat dilakukan secara intraoral maupun eksterna. ${ }^{1-}$ 3,11 Pada pasien ini dilakukan insisi secara intraoral karena absesnya sudah pecah. Dalam salah atu studi insisi intraoral dan drainase dilakukan pada $73 \%$ sampai $94 \%$ kasus. ${ }^{18}$ Insisi peroral dapat dilakukan melalui dinding posterior faring. Kepala penderita dalam posisi "Rose" agar pus tidak masuk trakea. Selanjutnya dilakukan insisi pada mukosa kemudian dimasukkan arteri klem pada rongga abses agar terbuka lebar. Alat penghisap harus disediakan untuk menghisap pus yang keluar. Antibiotika intravena dapat segera diberikan tanpa menunggu hasil kultur dan sensitivitas kuman. Antibiotika sefalosporin generasi terbaru atau kombinasi aminoglikosida dan sintetik penisilin merupakan pilihan saat sekarang. ${ }^{17}$ Seftriaksone merupakan golongan sefalosporin generasi ketiga yang baik untuk bakteri gram positif dan negatif. ${ }^{12}$

Kuman aerob yang tersering ditemukan adalah Streptococcus piogenes, Staphylococcus yang merupakan aerob gram positif dan Klebsiella yang

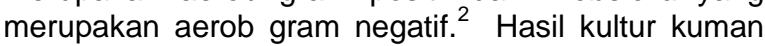
yang diambil dari pus pasien adalah Staphylococcus aureus. Sedangkan hasil kultur sputum pada pasien adalah Klebsiella sp, Pseudomonas aeruginosa dan tidak ditemukan kuman BTA.

Staphylococcus aureus merupakan kuman aerob tersering yang ditemukan ${ }^{2}$ dan kuman sensitif terhadap seftriaxone. Gambaran mikrobiologi abses retrofaring tersering adalah infeksi campuran antara aerob dan anaerob. Bakteri aerob yang dominan adalah streptococcus, staphylococcus aureus dan Klebsiella. Akhir-akhir ini Klebsiella merupakan kuman yang paling sering ditemukan. ${ }^{10,11}$ Ditemukan juga Pseudomonas aeruginosa pada kultur sputum pasien. Pseudomonas adalah batang gram negatif aerob. Kolonisasi kulit penderita, mukosa hidung dan tenggorok adalah rendah pada saat masuk rumah sakit tetapi bertambah sampai $50-70 \%$ pada rawat inap yang lama dan penggunaan antibiotik spektrum luas. ${ }^{14}$ Pemeriksaan mikrobiologis dapat dilakukan secara apusan langsung atau biakan kuman. Pemeriksaan bilas lambung dilakukan tiga hari berturut-turut minimal 2 hari. Hasil pemeriksaan mikroskopik langsung pada anak sebagian besar negatif. Sedangkan hasil biakan memerlukan waktu lama yaitu sekitar 6-8 minggu. ${ }^{15}$ Pada pasien ini dilakukan pemeriksaan biakan kuman.

Pasien diberikan preparat steroid yaitu dexamethasone selama 10 hari. Efikasi dan kelayakan penggunaan preparat steroid dalam penanganan kasus abses retrofaring belum jelas. Dalam studi retrospektif didapatkan tingkat penggunaan steroid lebih pada $20 \%$ kasus tetapi tidak disebutkan keuntungan penggunaannya. ${ }^{18}$ Bahkan salah satu penelitian menganjurkan agar tidak memberikan preparat steroid pada kasus-kasus abses leher dalam, akan tetapi tidak dilengkapi data-data yang mendukung. Penelitian Lalakea dkk menunjukkan kebanyakan Spesialis THT tidak memberikan steroid intravena pada kasus abses retrofaring. ${ }^{18}$

Kuman anaerob yang tersering ditemukan pada kultur adalah Bacteroides $s p$ dan Bacteroides melaninogenicus. ${ }^{14}$ Penggunaan metronidazole dikarenakan nanah yang keluar dari abses pasien berbau sangat busuk dan metronidazole sensitif terhadap kuman Bacteroides sp. ${ }^{12}$ Pada kasus ini tidak ditemukan kuman anaerob.

Benda asing sebagai penyebab abses retrofaring biasanya ditemukan pada pasien diatas lima tahun dan dewasa. ${ }^{2}$ Pada beberapa kasus, abses retrofaring non tuberkulosis disebabkan karena trauma pada faring dan esofagus terutama benda asing yang tajam. ${ }^{16}$ Pada pasien ditemukan riwayat ketulangan sepuluh hari yang lalu walaupun dalam eksplorasi benda asing (tulang ikan) tersebut tidak ditemukan. Singh $\mathrm{dkk}^{10}$ menyarankan untuk secepatnya mengangkat benda asing mengingat komplikasi yang dapat timbul seperti abses retrofaring.

Hasil foto polos thorak pasien adalah sugestif TB paru. Setelah dikonsulkan pada bagian IKA, dianjurkan untuk dilakukan kultur dan sensitivitas tes untuk penelusuran kuman banal dan dianjurkan uji Mantoux. Hasil uji Mantoux pada pasien adalah negatif. Pada populasi kulit berwarna kasus TB paru yang tersering adalah dewasa muda dan anak $<5$ tahun, sedangkan populasi terendah adalah 5-14 tahun. Uji tuberkulin (Mantoux) harus diukur oleh orang terlatih 48-72 jam setelah pemberian. Faktorfaktor yang terkait hospes, termasuk umur yang amat muda, malnutrisi, imunosupresi karena penyakit atau obat-obatan, infeksi virus, vaksin virus hidup dan tuberkulosis yang berat dapat menekan reaksi uji kulit pada anak yang terinfeksi dengan M.tuberculosis. Sebab-sebab uji negatif palsu yang paling sering adalah teknik yang jelek atau kesalahan dalam membaca hasil. Untuk anak-anak yang beresiko tinggi daerah reaktif $\geq 5 \mathrm{~mm}$ dapat digolongkan sebagai hasil positif.

Konfirmasi yang paling spesifik tuberkulosis paru adalah isolasi M.tuberkulosis pada pemeriksaan cairan pleura atau biopsi jaringan. ${ }^{14,15}$ Diagnosis TB anak ditentukan berdasarkan gambaran klinis dan pemeriksaan penunjang seperti uji tuberkulin, foto thorak dan pemeriksaan laboratorium. ${ }^{15}$

Hasil foto thorak pasien ini adalah infiltrat di perihiler dan parakardial disertai penebalan hilus dan perpadatan. Gambaran foto thoraks pada TB tidak khas. Kelainan-kelainan radiologis pada TB dapat juga dijumpai pada penyakit lain. Secara umum, gambaran radiologis yang sugestif TB adalah: pembesaran kelenjar hilus paratrakeal dengan/ sputum, bilas lambung, cairan serebrospinal, tanpa infiltrat, konsolidasi segmental/ lobar, milier, kalsifikasi dengan infiltrat, atelektasis, kavitas, efusi pleura dan tuberkuloma. ${ }^{15}$ Dengan demikian pemeriksaan foto thorak saja tidak dapat digunakan untuk mendiagnosis $\mathrm{TB}$, kecuali gambaran milier. ${ }^{15}$ 


\section{Daftar Pustaka}

1. Gadre AK, Grade KC. Infection of The Deep Spaces of The Neck. Head and Neck Surgery Otolaryngology. Second edition. Edited by Byron J Bailey. LippincontRaven Publisher, Philadelphia. 2006:665-84.

2. Schumrick KA, Shet SA. Deep Neck Infection. In: Paparella, Schumrick, Glucman, Meyerhoff. Ed. Otolaryngology Head and Neck. WB.Saunders Company. Vol. III $3^{\text {rd }} 1991$ : 2545-62.

3. Al-Sabah Basel. et al. Retropharyngeal abscess in children: 10-years study. The Journal of Otolaryngology. Vol 33. Number 6. 2004: 352-55

4. Maran AGD. Benign Diseases of the Neck. In: Stell $P M$ ed. Scott-Brown's Otolaryngology $5^{\text {th }}$ ed, Laryngology. London: Butter wotths \& C, 1997; 6:5/16/15-6

5. Ballenger JJ. Infection of the Facial Space of the Neck and Flour of the Mouth. In: Disease of the Nose, Throat, Ear, Head \& Neck. Lea \& Febinger, Philadelphia 1996;15:532-55.

6. Ahmad D, Pampori RA, Wani Aa, Qazi SM, Ahad SA. Transcervikal Foreign Body. The Journal of laryngology \& Otology. 2000;112:471-72.

7. Mehta AK, Panwar SS, Verma KK. Retropharyngeal Foreign Body. MJAFI.2004;60:390-1

8. Craig FW, Schunk JE. Retropharyngeal Abscess in Children: Clinical Presentation, Utility of Imaging, and Current Management. Pediatrics 2003;111:1394-8.

9. Avecedo JL, Shah RK. Retropharyngeal abscess. Available from: URL http: /emedicine.medscape.com/article.overview. Article last update, Mar 16, 2009. May 2009

10. Singh I, Chandra R, Gupta KB, Yadav. Fatal Pyothorax: A Rare Complication of Retro pharyngeal Abscess. Indian J Chest Dis Allied Sci 2003;45:265-8.
11. Kahn Joseph H. Retropharyngeal abscess. Available from: URL http:/emedicine.medscape.com/article/764421 overview. Article last update, Jan 23, 2008. May 2009

12. Ehrenpeis S, Ehrenpeis E. Clinician's Handbook of Prescription Drugs. New York: Mc Graw-Hill, 2001. p 180-182

13. Arfin Ann M. Infeksi yang disebabkan Pseudomonas. Dalam: Nelson, Ilmu Kesehatan Anak. Volume 2. Edited by Waldo E. Nelson. EGC. 1999. hal. 980-982.

14. Starke Jeffrey R. Tuberkulosis. Dalam: Nelson, IImu Kesehatan Anak. Volume 2. Edited by Waldo E. Nelson. EGC. 1999. hal 1028-1043.

15. Rahajoe N, Basir D, MS Makmuri, Kartasasmita Cissy B. Pedoman nasional tuberkulosis anak. Edisi 2. UKKRespirologi PP-IDAI. April 2007. hal. 23-46. hal 67-94

16. Srirompotong $S$, et al. Retropharygeal space infection. J Med Assoc Thai. 2004; 87 (4). 382-5.

17. Page Nathan $C$, et al. Clinical features and treatment of retropharyngeal abscess in children. Journal Otolaryngology-Head and Neck Surgery. 2008. 138. 300-306.

18. La Lakea $L M$, et al. Retropharyngeal abscess management in children : current practice. Journal Otolaryngology Head and Neck Surgery 1999; 121. 398-405.

19. Parhiscar A, Har-el, G. Deep neck abscess: a retrospective review of 210 cases, Ann. Otol. Rhinol. Laryngol 110: 2001: 1051-1054.

20. Fachrudin D, Helmi. Penatalaksanaan Infeksi Leher Dalam. Up-date 1995 Prinsip Dasar Penatalaksanaan Penyakit Infeksi. Dalam rangka Dies Natalis UI ke 46. 17 Juni 1995.

21. Larawin V, Naipao J. Head and neck space infections. Journal Otolaryngology Head and Neck Surgery 2006; 135. $889-893$ 